\title{
Sexuality and Questions of Gender in Adolescence: Contributions of Psychoanalysis
}

\author{
Sonia Alberti ${ }^{1, * *} \mathbb{D}, \&$ Heloene Ferreira da Silva ${ }^{1}$ \\ ${ }^{1}$ Universidade do Estado do Rio de Janeiro (UERJ), Rio de Janeiro, RJ, Brasil
}

\begin{abstract}
The institutional clinical practice with adolescents in a university hospital in the present times raises questions about both gender and sexuation. Such questions are not exclusively at the level of practice, but also of theory, requiring it's refinement. We introduce it in the context of psychoanalysis. Methodologically, we left the clinic to question the theory, allowing it to be enriched, as Freud wanted, from the beginning, when he observed that in psychoanalysis there is no theory without clinic. Although we are based on psychoanalytic authors, we do not fail to imply references in authors of the connection fields of psychoanalysis, which often bring fundamental elements to the intended refinement. We conclude by presenting a case to exemplify the questions that led us to the research.
\end{abstract}

KEYWORDS: psychoanalysis, adolescence, gender, sexuation, clinical cases

\section{Sexualidade e Questões de Gênero na Adolescência: Contribuições Psicanalíticas*}

\begin{abstract}
RESUMO - A prática clínica institucional com adolescentes em um hospital universitário atualmente levanta questões tanto sobre gênero quanto sobre sexuação. Tais questões não se colocam exclusivamente a nível da prática, mas também da teoria, exigindo um afinamento desta. Introduzimo-lo no contexto da psicanálise. Metodologicamente, partimos da clínica para questionar a teoria, permitindo enriquecê-la, como queria Freud desde o início, quando observava que, em psicanálise, não há teoria sem clínica. Apesar de nos basearmos em autores psicanalistas, não deixamos de implicar referências em autores dos campos da conexão da psicanálise, que muitas vezes trazem elementos fundamentais para o afinamento pretendido. Terminamos com a apresentação de um caso para exemplificar as questões que nos levaram à pesquisa.
\end{abstract}

PALAVRAS-CHAVE: psicanálise, adolescência, gênero, sexuação, caso clínico

Is the proliferation of sexualities closely followed by the proliferation of new sexuality terminology or do subjects identify with new terms as they emerge? As a preamble, it is worth pointing out the following: the concept of gender identity differs from that of sexual orientation. Thus, in the LGBTQI+ acronym (the list is not exhaustive, hence the "+"), the first three letters refer to sexual orientation (lesbian, gay, bisexual), while the last four - with intersex being a particular case - refer to gender identity (transgender people, queers, intersex people). Sexual orientation refers to an enduring pattern of emotional, romantic and/or sexual attraction to another person, while gender identity is the inner feeling of being masculine, feminine or anything else. Transgender people can be heterosexual, lesbian, gay, bisexual or asexual, as in the case of cis people. The LGBTTQI community defines cisgender - the Latin prefix cis means "on this side of" - someone whose gender identity matches the sex they were assigned at birth, while people whose gender identity and/or gender expression differs from the traditional societal norms and expectations associated with the sex they were assigned at birth are called "trans" (cf. Standards of Care for the Health of Transsexual, Transgender, and Gender Nonconforming People, 2012).

Current clinical practice with adolescents requires that the psychoanalyst has a deep understanding of gender issues and questions prejudice - which can occasionally still be

\footnotetext{
* Apoio: CNPq; FAPERJ

**E-mail: sonialberti@gmail.com

n Submetido: 01/02/2017; Revisado: 02/10/2017; Aceito: 09/10/2017.
} 
found within the field of psychoanalysis - and has made valuable contributions to the advancement of psychoanalytic theory. Indeed, it could be said that psychoanalysis was born at a time in which certain clinicians and intellectuals were beginning to question cisheterosexuality, which viewed those who did not fit in as deviant or perverted. However, it was largely the social movements that emerged in the early twentieth century that shook old certainties once and for all.

At the end of his epic analysis of Little Hans, Lacan (1956-1957/1995) addresses the question of choice of masculinity drawing from Freud's post-writings (1922/2015) regarding an episode when young Hans said that he remembered absolutely nothing about his treatment when he was little. Lacan likens Hans to a certain kind of young people who have "two mothers" rather than one due to the absence of a father. This makes Lacan articulate Hans with the Leonardo da Vinci analyzed by Freud (1910/2013), on the one hand, and a certain kind of young people from the generation of 1945 who "wait for the initiatives to come from the other side" - the side of woman - who wait for women to "unbutton them", on the other (Lacan, 1956-1957/1995). Hans no longer dreams of playing hide-and-seek with little girls or showing them anything other than himself, "something like a fetish object", where little Hans is "situated in a position that is passive" (Lacan, 1956-1957/1995, p. 342). Hence, "whatever the heterosexual legality of his object, we cannot consider that it exhausts the legitimacy of his position." (Lacan, 1956-1957/1995, p. 342). Though they may appear heterosexual, the masculinity of these young people has been compromised by what Lacan identified as the so-called phallus dentatus, the maternal phallus, lurking for any possible movement of aggressiveness towards an object, being itself "a sort of fixed [...], imaginary object" that will always victimize and hurt the one who performs a masculine assault (Lacan, 1956-1957/1995, p. 342). Lacan concludes that, though he may appear heterosexual, that is the future of "this charming little Hans", a "young knight".

The date was by no means insignificant. In 1945, numerous young people across Europe had been deprived of the presence of their fathers, felled on the battle grounds, never to come home or, at best, so damaged by what they had been through in the war that they did not know what manner to assume towards their children - often left without a father for years, exactly in the phase that they most needed them - the function of the real father, he who castrates.

However, other readings of this theme suggest that Lacan was not bound by this date. It is a complex question. Indeed, it is this question that sustains the cruelty of initiatory rites so often explored by other fields, which demonstrate that it is not a question of the past, since if these rites are the cutting edge that guides puberty towards masculinity, it is often to uphold the maxim of manhood. This is what the authors cited by Lattanzio (2011) suggest in his examination of the function of adolescent initiatory rites as a way of ridding boys of the femininity they have been infected with since the time they were in the womb. Here we refer in particular to the interesting contributions made by Tubert (1999) regarding rites in the Asaro Valley in Papua New Guinea, where boys live with their mothers, having little contact with their fathers. When puberty arrives, the boys are isolated from their mothers and purified of their previously embodied femininity by bleedings, while their mothers literally enter a period of mourning "in recognition of the separation from their children, who formally pass to the masculine part of society" (Tubert, 1999, p. 66). The bleedings and vomiting brought on by the manipulations of the boys' bodies by adult men "release the boy from the maternal blood he swallowed while in the womb and from the dangerous menstrual blood he may have unknowingly ingested with the food his mother prepared for him" (Tubert, 1999, p. 67). After some years living apart in the "men's huts", the boys become adults and marry. The separation from the mother is final. Freud $(1908 ; 1913$; 1917) made repeated observations of one of the symptoms of this process - the fear of menstrual blood. Lattanzio (2011, p. 140) writes: "the boys (who have) become men [heterosexual and married] begin to have a relationship of fear of women's menstrual blood, which could even kill a man and represents the constant threat of feminization". A teenager said on one occasion during a session: "I'm very extrovert, but when I am near a woman I get really nervous. Women are my kryptonite".

The following text is from a study of weekly clinical practice with adolescents conducted over the last few years in a psychoanalysis and mental health clinic in a university hospital. The study used the following guiding question: what are the specificities of today's sexuations during adolescence and how does this practice affect psychoanalytic theory? Consequently, the methodology used departs from clinical contributions that question and therefore enrich theory when we propose theoretical development as one of the aims of psychoanalytic research. We rely on the following statement made by Lacan: "the subjective configuration has an objectivity that can be perfectly well mapped out and grounds the very possibility of the help that we contribute in the form of interpretation" (Lacan, 1969-70/1992, p. 82). For this enrichment, we depart from a literature review, compare the results of the review with clinical practice and raise hypotheses for possible theoretical advances. 


\section{THE AFFECTS OF YOUTH}

Having partially overcome the confusion about the difference between sexuality and the sexual act that prompted research on AIDS among younger people and teenage pregnancy, current research on adolescence gives precedence to the theme of gender identity and sexual orientation.

The question of the sexual identity of the subject is something that is always addressed in terms of the Other, as is the case with initiatory rites. Today, the role of the internet in the search for the answers that adolescents can obtain in the digital world is undeniable, as shown in the following question asked by an adolescent of the analyst: "Why do we choose to like someone who doesn't like us? This is a question that Daddy Google doesn't answer. Because if the dictionary was the Father of the fools of your generation, Google is the father of the desperate of mine". Analysts are also a product of their time and should not ignore the advances of their era: in this case, social media, which dictates what subjects should do and their identity, which, it should be stressed, is in no way related to the civilized sexual morality of yesteryear that set the norms of how things should be done as a man and as a woman. What affects the youth of today is diversity. Gallano pointed out as early as 2006 that "today subjects do not find the Other who normalizes the difference between the sexes" (Gallano, 2006, p. 317).

Without doubt, the way in which this difference was once transmitted used to be underpinned by the clear identification of the paternal function with the real father, which is something that is not necessarily observed today. Psychoanalysis emerged at a time in which the vacillation of this identification became evident; the father was no longer enough in Freud's time. One of his contemporaries, Wedekind, wrote the play Spring Awakening (Wedekind, 1891/2008), in which the function of the Masked Man is to replace the father to symbolically support him - the function of sustaining the desiring subject. Melchior, to whom the Masked appears, wonders if he is his father. Today, when "the subject wants a father's support to sustain (his/her) steps to face the vicissitudes of the desire of the Other, (he/she) no longer finds the father who watches over him" (Quinet, 2002, p. 119).

In this second decade of the new millennium, we are witnessing the teenage body free falling into the enigma of sexual relation. We cannot deny the political, social and aesthetic impacts of new information and communication technologies on the enactment of gender significations that do not correspond to the anatomical facticity of sex, the semblances that the era inscribes on the body. If we consider the Lacanian warning "Let whoever cannot meet at its horizon the subjectivity of his time. [...] Let him be well acquainted with the whorl into which his era draws him into the ongoing enterprise of Babel" (Lacan, 1953/1998a, p. 322), it might be said that psychoanalysis should not simply dismiss gender issues and feminist positions or queer theory studies that propose the dismantling of bipolarity. If in 1970 Lacan stated that it is "embodied that [language] structure drives affect" (1970/2003, p. 406), one might speak of "affects of an era, and even of youth" (Pollo, 2003, p. 69) that mark the subject's own body.

Although gender is not a psychoanalytic concept, there is no denying the discursive effects produced by putting it into question. As Ceccarelli (2010) observes, there are two often conflicting perspectives of gender in psychoanalysis: "the intersection of what constitutes the individual - of the constitution of the subject - and social constructions as tributaries of historical processes". According to Leila Dumaresq (2014), a transgender woman and activist who holds a degree in philosophy, both outside and inside psychoanalysis, the question of gender is sustained in the speech of the subject and treated primarily as a political issue. She proposes a "transgender sex policy". Her Parrhesia is "my place of speech is my experience and critical living with my condition. [...] To testify to who we are with our words is a fundamental act of resistance. And few words will not be used for so many true ways of being" (Dumaresq, 2014). Her policy proposes that society respects differences that mark people, individuals and subjectivities, going against dehumanization, marginalization and exclusion. This theme also brings into question us analysts: what do we mean to say by sexual difference?

Psychoanalytic clinical practice with adolescent subjects illustrates the impasses subjects experience in confronting the impossibility of a relationship of completeness between the sexes, providing the opportunity to address a littledebated and by no means simple question. A question that is particularly enlightening when it comes to the problem of choosing a sexuated position during adolescence - a time when vacillations of identification inherited from childhood are known to occur (Alberti, 2004). The casecentered psychoanalytic approach has the chance of being heard within this imbroglio, where it is clear to parents and experts alike that adolescents are "experimenting with" new identities and are not sure whether they are men or women. 


\section{ADOLESCENCE AND CHOICES}

It is important to stress that adolescence is a time of choices, bearing in mind "there is no choice without prior indications, directions, determinants" (Alberti, 2004, p. 10). These directions come not only from parents and educators, but also from "peers, the media, the world around (them)... transmitted by spoken, written, visual, and communicative language, or even by silence, which is, nevertheless, a form of language" (Alberti, 2004, p. 10). Moreover, the constitution of sexuality, which according to Freud is categorically infantile (1905/1996a), also comes before adolescence. Freud would say that sexual life has an essentially biphasic character, interspersed with latency: childhood on one side and the adolescent on the other, with the definitive constitution of sexual life occurring in puberty (Freud, 1905/1996a, p. 189). Is there actually a definitive choice of sex in adolescence? Or is this idea of Freud outdated? Is it supported by the idea that sexual difference may lie between the phallic premise of child sexuality and the encounter with the Other sex in adolescence? (cf. Alberti, 2004).

The biologist Anne Fausto-Sterling (1993) asserts: "biologically speaking, there are many gradations running from female to male; [...] one can argue that along that spectrum lie at least five sexes - and perhaps even more. [indeed] sex is a vast, infinitely malleable continuum that defies the constraints of even five categories." (p. 2). Years later, she adds that it is the complexity of the sex of the human body that prevents "this or that" (Fausto-Sterling, 2001-02/2000, p. 15) and that labeling someone a man or woman is a purely social decision based on our beliefs about gender - not science - where "our beliefs about gender affect what kinds of knowledge scientists produce about sex" (Fausto-Sterling, 2001-02/2000, p. 15).

In a footnote added in 1915 to his "Three Essays on the Theory of Sexuality", Freud (1905/1996a) clearly states that the concepts of "male" and "female" are among the most confusing scientific concepts since they are broken down into at least three distinct senses: "activity" and "passivity", the biological sense (sperm or eggs), and the sociological sense (real men and women). According to Freud, the first of these senses is essential for psychoanalysis, since libido is a masculine force and drive is always active, even when it sets itself a passive target. As we know, Freud equated masculinity with activity and femininity with passivity. But this does not mean he suggests that men are active and women are passive! Quite the contrary, since he states that achieving a passive aim may call for a large amount of activity (Freud, 1931/2010a) and regards bisexuality as the "decisive factor": "In all of us, throughout life, the libido normally oscillates between the male and female object" (Freud, 1920/2011d, p. 130). To Freud, male and female refer not only to the development of boy and girl, but also the way in which each subject deals with the recognition of difference. Anatomy is given; what is not given is how subjects view their anatomy. This view comes into play in gender differentiation.

Freud (1933/2010b) states that the driving force of sexual life is the libido: "This sexual life is dominated by the polarity, masculine-feminine; one is therefore tempted to consider the relation of this libido to this polarity" (p. 288), since "there is only one libido which is as much in the service of the male as of the female sexual function". Right at the beginning of "Femininity" (Freud, 1933/2010b), reexploring the distinction between "male and female", Freud writes: "what constitutes masculinity or femininity is an unknown element, which is beyond the power of anatomy to grasp" (p. 266).

Discourse is incapable of correcting or dealing with the sexual "denaturalization" of the subject (cf. Lesko, 1996), meaning that all we have is a reference to the phallic signifier, producing consequences that are always insufficient for subjects to position themselves within the partition of the sexes. Based on this reference, the subject makes a double choice: the choice of the sexuated position - in which he/she assumes responsibility for "his/ her jouissance" (Quinet, 2013, p. 131) - and the choice of his/her sexual object. This, of course, rules out anything that does not refer to the phallus, the reason why the choice of sex is also "the choice of the not-all [...] that gives up its place to the Other of sex" (Strauss, 2015, p. 76). The not-all is the hole in the sex of the woman, "that refers the subject to his/her own impossibilities, which he/she does not understand, which he/she perceives, but is unable to signify" (Alberti, 2004, p. 31). Impossible to symbolize, this "hole resends every adolescent, regardless of his/her culture, to an unrepresentable point, to the real at stake in the encounter with sex" (Alberti, 2004, p. 31). This is how Lacan definitively subverts each and every interpretation of sexuality within psychoanalysis. Sexuality is not bipolar because he defines existence symbolically with reference to the phallic signifier: the existence of any subject, on the one hand, however he/she wishes to identify him/her self and regardless of biological constitution, and nonexistence on the other, which leads Lacan to conceptualize, logically, that "the Woman does not exist" (Lacan, 1971/2009, p. 69). 


\section{THE LOGIC OF SEXUATION}

Lesko (1996) criticizes taken-for-granted assumptions about adolescents from an archaeological perspective (in the Foucauldian sense of the term) of femininity, which resists being inscribed in the form of knowledge. This prompts us to ask, as does Prates (2001): "how should one understand, on a plane other than clinical structures, 'decision making' in relation to sex"? (Prates, 2001, p. 95). To answer this question, the author reexplores the question of Lacan's use of formal logic in his teaching and considers it to be of inestimable importance, "in the sense that it contextualizes the discussion on a plane that is neither phenomenological, nor from the order of natural language" (Prates, 2001, p. 95). She points out that the words "man" and "woman" are widely used and imbued with cultural significations, which makes it all the more important to pay attention to the theoretical treatment Lacan gives these terms, in order to elevate them to the status of psychoanalytic concepts. According to Prates, Lacan's rereading of these terms is not casual, since "they show courage in not shying away from a clinical problem that has been present throughout the history of psychoanalysis, namely: after all, how does the psychoanalyst know whether he is before a man or a woman?" (Prates, 2001, p. 96).

Lacan first wrote his formulas of sexuation in 1973, logically formalizing their two levels. With regard to the upper part, with its four propositional formulas - which we will not go into here - he postulates "Those are the only possible definitions of the so-called man or woman portion for that which finds itself in the position of inhabiting language" (Lacan, 1972-73/1999, p. 80). Whereas the part underneath is "what is improperly called humanity insofar as humanity is divided up into sexual identifications". Lacan (1972-73/1999) is quite clear when, in reference to sexual meaning, he says "Because it is impossible to say, the only sense is it's direction: to incompleteness, where there is no meaning. Reason why any other sense different from direction, fails" (p. 79). Regarding his formula, Lacan states: "It doesn't strike me as exemplary, if not, as usual, in producing misunderstandings" (p. 78). Lacan (197172/2012) had already stressed that the essential point, the point of emergence of the speaking being is the disturbing relationship with the body, which he called jouissance. Jouissance as an effect of language suffers the blow of castration.

Establishing that the difference between man and woman is a question of logic removes all loopholes for biology. The term "sexuation" proposed by Lacan (1972-73/1999) ultimately identifies the man and the woman by his/her mode of jouissance. It could be said that it amounts to the formalization of the impossible, implying the real (Miranda \& Alberti, 2012). Lacan proposes a discourse that stems from the real, based on logic, which is produced with the need for a discourse (1971-72/2012). What decides which side of the sex partition someone is on?

Quinet's (2013) reading of the formulas of sexuation reexplores two distinct logics: the phallic logic of the One that constitutes an exception, forming a closed set that articulates the One with the whole of the phallic battalion of men; and the logic of heterity of the Other sex, of the not-all of the feminine side - Other because it is heterogeneous in relation to the One, hence Heteros.

Lacan said in 1972 that from birth there is an innate and natural difference that is real "for the fact that in the species that names itself Homo sapiens [...] the sexes seem to be split up into two roughly equal numbers of individuals much earlier than expected. It should be recognized, however [...] we distinguish them, not them who distinguish themselves" (Lacan, 1971-72/2012, p. 15-16).

Emphasizing that the binary classification of sex is a totally logical necessity, Soler (2013, p. 121) proposes two heterogeneous alternatives, both of which might be said to be real: between male and female, in the sexuated being, and between man and woman, in the speaking being, emanating from logical determinations of language.

The sexuality of the subject is forever inscribed in the Oedipus complex, which is twofold, positive and negative (Freud, 1923/2011a) - because the latter is related to desire: "the central phenomenon of the sexual period of early childhood" (Freud, 1924/2011b, p. 204), dependent on the bisexuality of the child. It is worth remembering that in his letter to Fliess in 1899 Freud writes: "Bisexuality! [...] And I am accustoming myself to regarding every sexual act as an event between four individuals" (p. 46). And, in 1905, Freud already knew that the male-female segregation so vehemently claimed by civilized morality at the time does not exist in nature.

When Lacan (1971-72/2012) takes the denaturalization of sex to its ultimate consequences, he identifies a tendency towards the obnubilation of the real of castration in the function and field of speech and language. In the way it is treated in the articulation with the being, language performs an anecdotal function that supersedes jouissance, while sustaining itself in the phallic function, which protests castration - as, incidentally, Freud (1937/1996b, p. 287) postulated in his idea of "rejection of femininity", replacing the notion of "male protest" proposed by Adler (cf. Rocha, 2002, p. 143). Indeed, if "the castration complex always acts in the sense of its content, inhibiting and limiting masculinity and encouraging femininity" (Freud, 1925/2011c, p. 296), the castration complex that implies rejection of femininity is a way of escaping it through smuggling. Language always operated in that which concerns sexuality, constructing 
myths to account for what it is impossible to say and therefore associated with the scientific register "and the symbolic language of myths and legends" (Rocha, 2002, p. 131). However, myths and legends are also sustained in the imaginary and therefore in the penis itself as consistency, which sometimes fooled even Freud himself, particularly at the beginning of psychoanalysis when he identified the penis with masculinity. This is exactly what Lacan calls "anecdotes" in his Seminar ...or Worse (1971-72/2012) and what he seeks to break down, once and for all, when, as Miller (2012) observes, the One is used as the real, rejecting the two of the signifying articulation. This One is a new, real and pure mode of articulating castration, promoting a new vector, which goes from the real to the symbolic, a non-anecdotal vector. That is why Frege's idea of propositional function is so important to Lacan, since it expresses logical forms within a symbolism devoid of ambiguity. If the phallic function is within language, castration ex-sists it. And this is not unrelated to the unconscious content, because it is exactly with the use of logic that one can dispense with the principle of contradiction which, as Freud already proposed, is not in the unconscious. Castration, an unbridgeable hiatus, can only be approached from logic: since the object of logic is imposed by a need for discourse (Lacan, 1971-72/2012). This need ultimately rejects the Other as the axis of the dialectic of the subject and turns it to fiction, devalues desire, promises jouissance, and rejects the being, which is nothing more than semblance and, ultimately, henology - the theory of the One - overcomes ontology - the theory of the being (Miller, 2012).

The logic of sexuation breaks down, once and for all, each and every natural reference concerning the sexuation of the speaking being.

\section{SEX AND GENDER}

At the end of Gender Trouble, Butler (1990/2018) outlines the idea that the body is not a "being" in the sense of having something to express. It is in fact "a variable boundary, a surface whose permeability is politically regulated, a signifying practice within a cultural field of gender hierarchy and compulsory heterosexuality" (Butler, $1990 / 2018$, p. 198). This is what the adolescent needs to come to terms with: gender is on the surface, it could be said that it is a "bodygender" (Knudsen, 2013). The idea that the body is a surface can also be clearly observed in Freud's works (1923/2011a). However, the idea that this surface makes the body the Other of the jouissance is still something to explore. We postulate that since the beginnings of culture, adolescence is the stage on which this is experienced more intensely.

Our research initially sought to delve deeper into the theme of teenage sexual awakening. Many of the adolescents we saw at the university hospital said they were "experimenting" and not sure whether they were men or women. These individuals could be hastily diagnosed with "gender dysphoria" (cf. DSM V, 2014), much in vogue these days, connoting what is known in the social field as new gender identities. For psychoanalysis, however, "dysphoria" concerns the core of all neurosis: what position should one take when the choice of sex is enforced? Since anatomy does not identify whether a subject is a man or woman, uneasiness about one's own sex is the rule for everyone. This is where psychoanalysis can offer a relatively original contribution, given that it considers that "there is no sexual identity; sexuality is the very thing that disrupts all identity" (Zupančič, 2016). According to Lacan (1971-72/2012, p. 33), "sexuality is, without doubt, at the center of everything that goes on in the unconscious. But it is at the center because it is a lack". And the adolescent must come to terms with this lack however he/she is able, as the below clinical situations extracted from the accounts of three adolescents who attended the clinic show:

1. "I'm a man in the body of a woman, but a man who likes men, a gay man", said one of the adolescents, clearly explaining the difference between her gender identity, or sexuated position - I'm a man - and her sexual orientation, or choice of object - a man who likes men. In the following sessions, the same adolescent stated: "I'm a woman who's the alpha male of the house", identifying her gender role as masculine, occupying the position in which she sees herself placed by her family, in other words meeting a demand of the Other.

2. "Us women get off on each other. All women are bi. Man with man is disgusting, but us no... Women hold hands, get changed together, shower... so we get off on each other, touch each other, experiment. Have you ever experimented? If you haven't it's because the right woman hasn't come along yet", an adolescent said explaining her feminine sexuality, agreeing with Freud (1931/2010a) when she highlights bisexuality has come to the fore in women's sex lives.

3. "My mum thinks I'm going to become a queer if I use an ear tunnel, but the only thing I can become is a homemsexual (literally "sexual man"), an adolescent said, presenting the "ear tunnel" as something that could separate himself minimally from his mother's words. In this case it is interesting to note the equivocality of language, or the misunderstanding of lalangue, which leads this teenager to hear the signifier of homosexual as homemsexual (cf. Alberti, 2017 , p. 83). It is this equivocality that provides the enabling conditions for separation. 
The presentation of the being-for-sex, which is the Freudian subversion of philosophy, adolescence is the logical time of work, driven by the real of the encounter with the Other sex, affected by the Spring Awakening (Wedekind, 1891/2008), which interrupts "the sleep of the dormant Oedipus complex" (Alberti, 2009, p. 20) when sexuality shows itself as a "disencounter", accentuating that there is no sexual relation.

For Butler, "Gender Trouble" seeks to undo the notion that sex is to nature as gender is to culture: "If the immutable character of sex is contested, perhaps this construct called "sex" is as culturally constructed as gender" (Butler, 1990/2018, p.25), meaning there is no distinction between the two. The segmentarity of cisheterosexuality highly oversimplifies the relationship between sex and gender and creates a division between what is a woman and what is a man. Butler's theory of gender performativity questions the extent to which teenagers and adults are free to construct the meaning of their gender attribution. The body materializes the aspects of sexuality that are unrepresentable in gender, but resignifies itself in performance, in so far as gender appears as a fictional production. In turn, Lacan asks: "Where does it inhabit, Jouissance. What does it need? A body. It takes a body to enjoy" (Lacan, 1971-72/2012, p. 28). We might say that it is during adolescence that it becomes more evident that the subject not only has a body but is a body and that the semblance emerges from his/her relationship with this body as a subject. Is this idea equivalent to Butler's notion of performance? Without going beyond its scope - clinical practice with each subject - psychoanalysis should not fail to make its contribution to a discussion that has at its core the question of sexuality, which Freud, ever since the foundation of psychoanalysis, elevated to the position of the cause and foundation of all human actions.

In the face of medical discourse, we might well ask whether the question of "new gender identities" is related to the conceptualization of identification within psychoanalytic discourse, given that the question of "sex" - traditionally viewed as biological in medical discourse - has nothing to do with biology anymore in psychoanalytic theory.

In psychoanalysis, identification refers to the concept of Ego, which occupies the most privileged place when it comes to identification and can obstruct the emergence of the subject, which, according to psychoanalytic theory, only emerges as such where it pierces through the identifications. In turn, sexuality draws the subject towards the field of drive, which is always partial. "That is where the essential lack lies, that is, that which can represent in the subject the mode, in his/her being, of what within him/her is male or female" (Lacan, 1960/1998b, p. 863). There is no access to the Other of the opposite sex except via the partial drives, "wherein the subject seeks an object to replace the loss of life he has sustained, due to the fact that he is sexed" (Lacan, 1960/1998b, p. 863), producing a fundamental asymmetry in the relationship between man and woman.

Analytical experience demonstrates that questions of gender and identification do not solve the impasse facing sex and sexuality. What should we say and listen to in clinical practice with adolescents today? We should keep not looking for meaning and valuing the holes. Adolescents keep teaching us.

\section{"YOU CAN ONLY BE HETERO OR HOMO IF YOU TRY BOTH" (MILA)}

To exemplify the clinical issues that led us to undertake this research, we outline below what can be said so far about the case of an adolescent we called Mila. According to the foundations of psychoanalytic theory, the sexuality of the subject is inscribed in the Oedipus complex because it is related to desire. Moreover, according to Freud, there is a "second efflorescence" of sexuality in puberty after the period of "latency". Therefore sex, gender, identification, and sexuation are concepts that clinical practice with adolescents is able to observe at the moment in which they are questioned in a "crossing-over of appearances" (Alberti, 2009). With the fall of the identifications, the subject faces the impossibility of a relationship of completeness between the sexes, with its anecdotes, to which he/she has access as a product of language.

The first person to bring Mila (fictitious name) to the clinic was her maternal grandmother, who asked for help for her granddaughter because she had not been able to leave the house for months since when she did she had "panic attacks". She was not going to school, said she wanted to be alone with her mother and that she wanted to die. This is despite the fact that the grandmother described her granddaughter as having always been very intelligent, standing out in her class and school contests. It was only in the second interview that Mila's mother came with her. She described her daughter as a "mãezona" (literally meaning "big mother", a mother figure), always willing to help and listen to everyone, but forgetting about herself. An excellent student, she had never been a rebellious teenager. The couple's only daughter, when she was born the mother already had three sons and the father already had a girl and a boy. "I was an old mother", Mila's mother said. She never wanted to have a daughter because she thought that "women always suffer a lot", principally "at the hands of men". Yet, paradoxically, she thought that her daughter's problem was the "lack of a man", that her daughter would feel better if she got herself a boyfriend. She also added that Mila had "been like a boy ever since she was little" (sic).

Trying to describe what she called "panic attacks", Mila said that when she went out all of a sudden looked 
as if they were "wearing masks" and everything became "misty" - which she associated with the fear she felt as a child during carnival because of the masks carnival goers used. Her heart would start racing, her legs would tremble and she felt like she was going to die. She said that she had thought of killing herself several times: "I haven't killed myself yet because of cowardice. I thought: 'oh no ... dying must really hurt', so I decided against it". Trying to recall the onset of her symptoms, she said she went to the same school for the whole of her primary education. She was loved by the teachers for being "the most intelligent", but her friends called her "soft little Mila", "shy"... She had only two friends. She was the only pupil who passed the entrance exams for the escola modelo (a selective public high school). The principal of her new school created a Facebook page for the class where she added all the students who had passed the entrance exams. In this way, the students met each other virtually before actually meeting physically. That is how Mila, hiding behind the computer, saw the "perfect opportunity to be another person" (sic). On her Timeline (the photos, stories and experiences that tell a subject's life story on Facebook), she showed herself to be outgoing, surrounded by friends, and nice, and got lots of "likes". When she actually went to the school, she maintained the facade for a time, surrounded by friends, but began to feel lonely: "and the mask fell away... I found myself alone and unhappy and became myself again".

Mila took two weeks to come back after the first interview. When she came back, she said she had had even more serious "panic attacks", "horrible attacks". She said that in these moments she needed a "familiar face", which has to be her mother. "It's always been the same: when I get sick it's her I need. I need to see her face. When I start getting better, she starts with her digs". The mother-daughter conflict is clearly evident from the beginning. Her mother nicknames her "heart of ice Mila" precisely because she looks at her and says: "I don't like you". When Mila approached the subject in an individual interview, she said that she did not like her mother because she did not trust her and she was not her friend: "she's just company, I've always liked my father better". Is this Mila getting her own back on her mother for her clearly stating that she never wanted her?

Mila's parents were separated and her father had died three years earlier of heart disease, for which he had to be admitted to hospital. Mila refused to go to the hospital or funeral. In her mother's own words: "Mila didn't shed a tear". The father suffered from heart problems and the daughter had a "heart of ice".

According to Mila, when her father was alive her mother always got in the way and disliked the fact that she liked her father. There was a scene that repeated itself when she was a child: her father used to call saying that he was coming over to pick her up and she said she wanted to go with her father. But when her father showed up at the door she didn't know whether she wanted to go or stay. So she would run off and lock herself in her room and her father would go home without her. With time, Mila started to go to her father's house practically every weekend, but her mother always used to call and ask: "is he mollycoddling you"? She said that it was awful, "how could my own mother make me think that of my dad"?

The sessions with Mila were not regular, because she would disappear. After a month without seeing her, only exchanging text messages, she appeared as a boy. She had cut her hair and was wearing boys' clothes. She said: "I cut my hair boy style. I'd had enough of that long hair". She said that she had decided to "try a girl": "do you remember when I said you can only be hetero or homo if you try both"? She talked about Ana, her girlfriend, as a girl who "experiences a lot of suffering". Ana's mother threw her out of the house when she found out she was a lesbian and when she was little she lived with her father and her stepmother, who used to stub out cigarettes on her body: "she's really traumatized". "What a choice!", the analyst observed. Suddenly realizing, Mila says: "true... It must be because we're so much alike. I fell in love with her because of the texts she sends me. I love writing to people, but nobody had ever written to me. My mum has never left me a love letter. Ana sends me beautiful texts; you have to read them... I feel loved for what she writes".

After another long absence, she sent a text in the middle of the night on a Sunday asking to be seen urgently. She said she had tried to kill herself because she couldn't stand her mother's "disdain" any longer: "I wanted to be missed. Since I never have been... I've thought about that ever since I found out she wanted to abort me because I was a girl. She never wanted to have a daughter". In the same session she said she had decided to change schools. Her school principal, who was against the decision, had told Mila that outside the school she would suffer a lot of prejudice because of the way she is, since eighty-five percent of the students at the school were gay, lesbian or bisexual and everyone accepted each other.

Mila was intransigent, however, and decided to change schools. In her words, she said she wanted to ditch everything that had nothing to do with what she felt now, "I need to construct my answers", she said before disappearing again. When she came back she was living with her maternal grandmother. With her hair dyed blond and wearing a pair of short shorts and low-cut top, Mila now had a boyfriend: a "soft" boy who did everything she wanted. Mila put her boyfriend down, "he's a bit silly, a bit of a wimp". She said that he wanted to study art, but she thought that there was no future in it and put him off.

Mila vanished again for some weeks and when she came back she had blue hair. When asked whether her new appearance had something to do with the film Blue Is the Warmest Colour?, she answered with another question: "the one with two lesbians getting off on each other? Of 
course not! How disgusting!". She said that, although she hadn't watched the film, she had read some articles about it in which the actors said they felt violated because the director asked them to record the scenes so many times. "How could I watch that"?, Mila asked. She said she only returned to the sessions for one reason: she was still with her boyfriend, but people still thought she was a lesbian, "why do people still think I'm a lesbian if I have a man at my side? I don't like women. I came out, but I've gone back in"!
After another long absence, Mila sent a text message: "it's your patient that most misses sessions here. I'm writing to thank you and to tell you I passed the Vestibular (university entrance exam)!". According to Mila, it was because of the sessions and having been accepted as she was that she felt "inspired" to want to go to university. She said that the analyst was "an essential piece of her jigsaw puzzle" and that if she hadn't had that encounter she would have still felt lost and confused: "I would still be a dependent girl without a voice".

\section{CASE DISCUSSION}

This case illustrates the questions raised in this article, demonstrating the following: 1$)$ the fact that there is no a priori inscription for sexuation; the subject needs to assume a position; 2) the options that are given within current culture are not without consequences for the manner in which an adolescent subject questions him/ herself today; 3 ) the subjective position within the sex partition is not unrelated to the profound questions that the subject asks him/herself about his/her place for the Other; 4) there is something that the subject needs to choose in reference to the separation from the Other that implies that he/she is a sexuated being, and 5) the importance of an encounter with an analyst - when the analysts does not put him/herself in the position of someone who has knowledge but, due to his/her function and abstinence, enables the subject to construct his/her own answer, whatever it may be.

Why so much repositioning? In the face of current culture, according to Mila, "You can only be hetero or homo if you try both". The question is consciously put to all adolescents, even if not all of them experiment the way Mila did. However, this does not mean that all adolescents today have the freedom to seek the answer the way Mila did. From soap operas to relationships with other adolescents, today's world no longer covers over homosexual relationships. While some people continue to be scandalized, TV scenes showing homosexual relations continue to spark outcry, and young people continue to verbally and physically attack and kill homosexuals on the street, it must be said that no one can escape this question, not even these subjects. Take the scene from American Beauty where Ricky Fitts' father, a retired US Marine colonel, projects his homosexuality - which he will later have to come to terms with - onto his son (cf. Alberti, 2004).

While gender on the birth certificate is normally based on anatomy, the latter commands neither desire nor drive. This gender may be a unary trait that marks the subject, yet the moment we identify it with the desire, the moment we write "S" (" $E s$ " in German), the barred \$, this subject is from the drive, in which the object is what is most variable (Freud 1915/2006). It is interesting to note that it was exactly these unary traits of this order, the insignias of what was assigned, the masks that were imposed, which troubled Mila: the masks that turned carnival goers into murderers, the paradoxical mask of her mother, the mask her mother imagined for her father, and the mask Mila wore when she found herself shy and without friends. However, Mila began to realize that they were just masks; that she could also wear masks, be the most popular and liked among her classmates in her new school, that she could play with masks, and that she could let them fall away. When this became clearer to Mila from her own analysis, the task imposed on her was to review her position as a being - to no longer be "a dependent girl without a voice" when facing something that is not always possible to say. There is something of the being that escapes speech, knowledge, vision, and hearing. The being in Wedekind's (1891/2008) play who finds itself sustained by the unusual presence of the masked man, merely a mask that draws him not to that which is no longer his father, but rather that which is within him to decide: he needs to construct his own answers, which, because they entail the unknown, may not necessarily be definitive. When the drive imprints its character on sexuality, love, desire and jouissance are functions that vacillate.

\section{CONCLUSION}

In the hospital, it is possible to observe the tension between the two different approaches to questions of sexuality. On the one hand, we have biomedical inquiry, characterized by the rigid binary definition of the difference between sexes, which classifies sexualities that do not fall into the category of man or woman as gender dysphoria.
On the other, we have the crossing-over of gender theories, which calls into question the unequivocal bipartition of the sexes, making the categories and labels more complex and slippery. Within the specificity of the hospital in which we work, we are given the opportunity to "dialectize" this same dichotomy, allowing the entrance of psychoanalytic 
discourse to resignify clinical practice. At the same time, this opportunity calls for a rereading of psychoanalysis itself, which we attempt to introduce here.

The adolescent is the being-for-sex par excellence, because, contrary to the being-for-death that philosophy is concerned with (cf. Lacan, 1967/2003), adolescent subjects experience the scansions so well presentified in the case of Mila, in which the comings and goings are cuts with the elaboration of not only love, but also desire and jouissance, with reference to the question of how she exercises her sexuality. Love in the register of the imaginary, in desire, in the symbolic and jouissance, and in the real. The disruptive moment of anguish displayed by Mila was when her "mask fell". However, since it was possible to talk about this during analysis, numerous questions, such as not being wanted by her mother and the father who she identified with, came to light. And as psychoanalytic discourse proposes that there is no subject without sex, just as there is no subject without politics, whatever the discourse, there is no reason why psychoanalysis with adolescents should not delve deeper into this.

Perhaps we are witnessing feminization, as Carneiro Ribeiro (2011) suggests when she says that embracing analytical discourse in the strength of its contribution to the new century means embracing the feminine position, the not-all, incompleteness, the hole in knowledge.

Irretrievably separated from the Other, unsupported, the only option for the subject of the unconscious is to attempt to recover in fantasy the little that is left over - a blind gaze, an inaudible voice - the complement of his/her being. If he/she is willing to pay the price of facing his/her truth, he/she may find a new knowledge and a space for creation. Embracing psychoanalysis also means betting on the word, writing, the speech of love. Without doubt a feminine bet (p. 188).

Psychoanalysis attempts to move from a logic of identity towards a logic of the position of jouissance, regardless of anatomy, inscribed in the field of choice and thus responsibility. Something that Mila did not shy away from.

Psychoanalytic theory requires fine-tuning to deal with cases like Mila's and those we see in public clinics such as the one in the hospital where we work. This is something that we must not shy away from. However, this fine tuning will only occur if we revisit conceptually and ethically the founding texts of psychoanalysis that guide us so that we are always mindful of the fact that the politics of psychoanalysis is that which embraces the subversion of the subject. In the context in which we work, it is the subversion of the adolescent subject that teaches us to advance theory.

\section{REFERENCES}

Alberti, S. (2004). O adolescente e o Outro. Rio de Janeiro, RJ: Jorge Zahar Editor.

Alberti, S. (2009). Esse sujeito adolescente (3a. ed.). Rio de Janeiro, RJ: Rios Ambiciosos.

Alberti, S. (2017). Dois. In M. Daquino (Org.), A diferença sexual: Gênero e psicanálise (pp. São Paulo: Agente Publicações.

American Psychiatric Association. (2014). Manual Diagnóstico e Estatístico de Transtornos Mentais ( $\left.5^{\mathrm{a}} \mathrm{ed}.\right)$. Recuperado de: http://c026204.cdn.sapo.io/1/c026204/cldfile/1426522730/6d77c9965e17b15/b37dfc58aad8cd47790 4b9bb2ba8a75b/obaudoeducador/2015/DSM\%20V.pdf

Butler, J. (2003). Problemas de gênero: Feminismo e subversão de identidade. Rio de Janeiro, RJ: Civilização Brasileira. (Originalmente publicado em 1990)

Carneiro Ribeiro, M. (2011). Um certo tipo de mulher. Rio de Janeiro, RJ: 7 letras.

Ceccarelli, P. (2010). Psicanálise, sexo e gênero: Algumas reflexões. Recuperado de http://ceccarelli.psc.br/pt/?page_id=1483

Dumaresq, L. (2014). Ensaio de epistemologia transgênera. Transliteração. Recuperado de http://transliteracao. com.br/leiladumaresq/2014/11/ensaio-de-epistemologiatransgenera/

Fausto-Sterling, A. (1993) Os cinco sexos: Porque macho e fêmea não são o bastante. Recuperado de http://docslide.com.br/ documents/anne-fausto-sterling-os-cinco-sexos.html

Fausto-Sterling, A. (2001-02). Dualismos em duelo. Cadernos Pagu, 17-18, 9-79. http://www.scielo.br/pdf/cpa/n17-18/ n17a02. (Originalmente publicado em 2000)

Freud, S. (1996a) Três ensaios sobre a teoria da sexualidade. In J. Strachey (Ed.), Edição Standard Brasileira das Obras Completas de Sigmund Freud (Vol. 7, pp. 117-231). Rio de Janeiro, RJ: Imago. (Originalmente publicado em 1905)
Freud, S. (1996b) Análise terminável e interminável. In J. Strachey (Ed.), Edição Standard Brasileira das Obras Completas de Sigmund Freud (Vol. 23, pp. 239-288). Rio de Janeiro, RJ: Imago. (Originalmente publicado em 1937)

Freud, S. (2006). Os instintos e suas vicissitudes. In J. Strachey (Ed.), Edição Standard Brasileira das Obras Completas de Sigmund Freud (Vol. 14, pp. 117-146). Rio de Janeiro, RJ: Imago. (Originalmente publicado em 1915)

Freud, S. (2010a). Sobre a sexualidade feminina. In Obras completas de Sigmund Freud (Vol. 18, pp. 371-398). São Paulo, SP: Companhia das Letras. (Originalmente publicado em 1931)

Freud, S. (2010b). Novas conferências introdutórias à psicanálise: A Feminilidade. In Obras completas de Sigmund Freud (Vol. 18, pp. 263-293). São Paulo, SP: Companhia das Letras. (Originalmente publicado em 1933)

Freud, S. (2011a). O Eu e o Id. In Obras completas de Sigmund Freud (Vol. 16, pp. 13-74). São Paulo, SP: Companhia das Letras. (Originalmente publicado em 1923)

Freud, S. (2011b). A Dissolução do Complexo de Édipo. In Obras completas de Sigmund Freud (Vol. 16, pp. 203-213). São Paulo, SP: Companhia das Letras. (Originalmente publicado em 1924)

Freud, S. (2011c). A organização genital infantil, um acréscimo à teoria da sexualidade. In Obras completas de Sigmund Freud (Vol. 16, pp. 283-299). São Paulo, SP: Companhia das Letras. (Originalmente publicado em 1925)

Freud, S. (2013). Uma recordação de infância de Leonardo da Vinci. In Obras completas de Sigmund Freud (Vol. 9, p. 113219). São Paulo, SP: Companhia das Letras. (Originalmente publicado em 1910)

Freud, S. (2015). Pós-escrito à análise do pequeno Hans. In Obras completas de Sigmund Freud (Vol. 8, pp. 256-273). 
São Paulo, SP: Companhia das Letras. (Original publicado em 1922)

Gallano, C. (2006). O que dizem gays e lésbicas? In As realidades sexuais e o inconsciente (pp. 316-325). Salvador, BA: Escola de Psicanálise dos Fóruns do Campo Lacaniano no

Knudsen, P. P. P. S. (2013). Psicanálise, gênero e singularidade. Revista Faac, 2, 195-202, Recuperado de http://hdl.handle. net/11449/125085.

Lacan, J. (1992). O Seminário, livro 17: O avesso. Rio de Janeiro, RJ: Jorge Zahar. (Seminário proferido em 1969-70)

Lacan, J. (1995). O Seminário, livro 4: A relação de objeto. Rio de Janeiro, RJ: Jorge Zahar. (Seminário proferido em 1956-57)

Lacan. J. (1998a). Função e campo da fala e da linguagem em psicanálise. In Escritos (pp. 238-324). Rio de Janeiro, RJ: Jorge Zahar. (Originalmente publicado em 1953)

Lacan, J. (1998b). Posição do inconsciente. In Escritos (pp. 843-864). Rio de Janeiro, RJ: Jorge Zahar. (Originalmente publicado em 1960)

Lacan, J. (2003b). Radiofonia. In Outros escritos (pp. .403-447). Rio de Janeiro, RJ: Jorge Zahar.

Lacan, J. (2008). O Seminário, livro 20: Mais, ainda. Rio de Janeiro, RJ: Jorge Zahar. (Seminário proferido em 1972-73)

Lacan, J. (2009). O Seminário, livro 18: De um discurso que não fosse semblante. Rio de Janeiro, RJ: Jorge Zahar. (Seminário proferido em 1971)

Lacan, J. (2012). O Seminário, livro 19: ... ou pior. Rio de Janeiro, RJ: Jorge Zahar. (Seminário proferido em 1971-72)

Lattanzio, F. (2011). O lugar do gênero na psicanálise. Da metapsicologia às novas formas de subjetivação. (Dissertação de Mestrado). Universidade Federal de Minas Gerais, MG, Brasil. Recuperado de http://www.bibliotecadigital.ufmg.br/ dspace/bitstream/handle/1843/VCSA-8J9G7E/disserta_o_ felippe_lattanzio_vers_o_definitiva__o_lugar_do_g_nero_ na_psican_lise.pdf? sequence $=1$

Lesko, $\overrightarrow{\text { N. }}(199 \overline{6})$. Denaturalizing adolescence: The politics of contemporary representations. Youth and Society, 28(2), 138161).
Miller, J. (2012). Apresentação. In J. Lacan, O Seminário, livro 19: ... ou pior (4a. Capa). Rio de Janeiro: Jorge Zahar.

Miranda, E., \& Alberti, S. (2012). A função do feminino para a noção de estrutura em psicanálise. Tempo Psicanalitico, 44(2), 371-387.

Pollo, V. (2003). Mulheres histéricas. Rio de Janeiro, RJ: Contra Capa Livraria.

Prates, A. (2001). Feminilidade e experiência psicanalítica. São Paulo, SP: Editora Hacker.

Quinet, A. (2002). Um olhar a mais. Rio de Janeiro, RJ: Jorge Zahar.

Quinet, A. (2013). A escolha do sexo com Freud e Lacan. In A. Quinet, \& M. A. C. Jorge (Orgs.), As homossexualidades na Psicanálise: Na história de sua despatologização (pp. 131140). São Paulo, SP: Segmento Forma.

Rocha, Z. (2002). Feminilidade e castração: Seus impasses no discurso freudiano sobre a sexualidade feminina. Revista Lationamericana de Psicopatologia Fundamental, 5(1), 128-151.

Tubert, S. (1999). A morte e o imaginário na adolescência. Rio de Janeiro, RJ: Cia das Letras.

Soler, C. (2013). A maldição sobre o sexo. In A. Quinet, \& M. A. C. Jorge (Orgs.), As homossexualidades na Psicanálise: $\mathrm{Na}$ história de sua despatologização (pp. 119-130). São Paulo, SP: Segmento Forma.

Strauss, M. (2015). A escolha do sexo: O que dizem disso? Stylus: Revista de Psicanálise, 30, 69-78.

Wedekind, F. (2008). O despertar da primavera $\left(3^{\mathrm{a}}\right.$ ed., M. A. S. Melo, Trad.) Lisboa: Editora Estampa. (Originalmente publicado em 1891)

World Professional Association of Transgender Health. (2012). Standards of care for gender identity disorders ( $7^{\mathrm{a}} \mathrm{ed}$.). East Dundee: WPATH.

Zupančič, A. (2016). Sexo, ontologia e subjetividade. Lavra Palavra. Recuperada de Entrevista a Randall Terada publicada no site: https://avrapalavra.com/2016/03/01/sexo-ontologiae-subjetividade/ 